\title{
Distribution extension of Hyalinobatrachium cappellei (van Lidth de Jeude, 1904) (Anura: Centrolenidae) across Central
} Amazonia

\author{
Pedro Ivo Simões* , Igor Luis Kaefer, Felipe Bittioli Rodrigues Gomes and Albertina Pimentel Lima \\ 1 Instituto Nacional de Pesquisas da Amazônia, Coordenação de Biodiversidade (CBIO). Av. Efigênio Sales, 2239, CP 478, Bairro Adrianópolis. CEP \\ 69011-970. Manaus, AM, Brazil. \\ * Corresponding author. E-mail: pedroivo@inpa.gov.br
}

\begin{abstract}
We report the occurrence of the centrolenid frog Hyalinobatrachium cappellei in Careiro, Amazonas, Brazil (Central Amazonia). Our records reduce a gap of approximately 1,500 km between the closest known records for this glassfrog, and confirm H. cappellei as geographically widespread in the Amazon Basin.
\end{abstract}

The glassfrog Hyalinobatrachium cappellei (van Lidth de Jeude, 1904) was described from the Saramacca river basin, Suriname, and later considered as a junior synonym of Hyalinobatrachium fleischmanni (Goin 1964). Recently, in an extensive review on the genus Hyalinobatrachium, Castroviejo-Fisher et al. (2011) used an integrative taxonomy approach in order to clarify the taxonomic relationships between these, and other similar species. The name Hyalinobatrachium cappellei was then resurrected, and the species $H$. crurifasciatum, $H$. eccentricum and $H$. ignioculus were all pointed as its junior synonyms. Apparently, $H$. cappellei has a widespread distribution in northern South America, especially across the Guiana Shield geological domain. However, the real extent of its geographic distribution in the Amazon Basin is still not clear.

The species was recently recorded (under the name Hyalinobatrachium crurifasciatum) in the southern limits of the Amazon Basin, in two localities in the state of Mato Grosso, Brazil (Rodrigues et al. 2010). This report strongly suggested that the distributional range of this centrolenid frog should include additional localities within the Basin, which comprises vast subsampled and/ or unsampled areas. Here we communicate the first record of Hyalinobatrachium cappellei for the state of Amazonas, Brazil (Central Amazonia).

Individuals of Hyalinobatrachium cappellei (Figure 1) were found on two occasions during field work along the BR-319 road, in the Madeira-Purus interfluve, southwest of the city of Manaus (Figure 2). The area comprises poorly sampled areas of primary terra-firme forests and swamp lands in the municipality of Careiro, state of Amazonas. Along the road, several sampling sites have been established by the Brazilian Government Program for Biodiversity Research (PPBio - http://ppbio.inpa.gov.br), where biodiversity surveys are now conducted regularly. Our first $H$. cappellei record consists of one male found on January $2^{\text {nd }} 2010$ in the locality of Igapó-Açu, at the km 260 of BR-319 road, corresponding to site 5 of PPBio (coordinates $04^{\circ} 36^{\prime} 21^{\prime \prime} \mathrm{S}, 61^{\circ} 14^{\prime} 56^{\prime \prime} \mathrm{W}, 53 \mathrm{~m}$ above sea level). This individual was found at night, calling from the underside of a leaf of an epiphytic herb (family Araceae), hanging over a small stream about $2 \mathrm{~m}$ above water level. A small egg clutch (nine eggs) was found on the same leaf, also hanging from the underside surface. The stream was located in the northern trail, 1,000 $\mathrm{m}$ from the sampling site's edge.

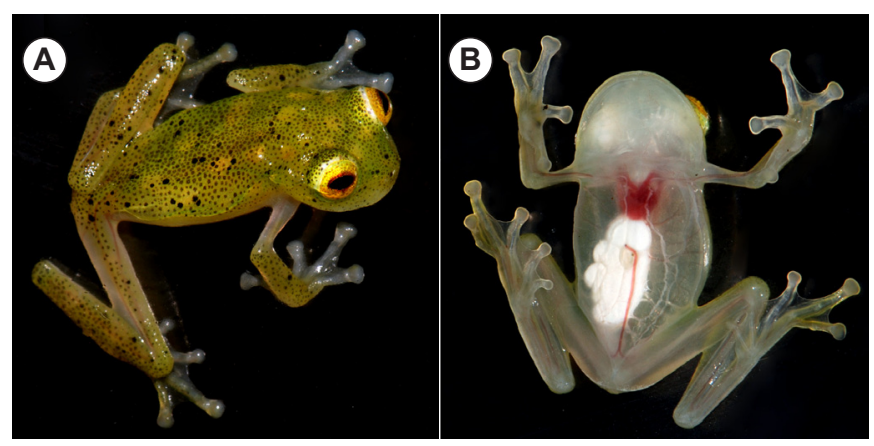

Figure 1. A) Dorsal view of male Hyalinobatrachium cappellei (INPA-H 28600) collected in February 2011, in the locality of Taquara, at the km 220 of BR-319 road, in the Municipality of Careiro, Amazonas. B) Ventral view of same specimen.

The second record consists of two males found on February $17^{\text {th }} 2011$, in the locality of Taquara, at the km 220 of BR-319 road, corresponding to site 4 of PPBio (coordinates $04^{\circ} 22^{\prime} 47^{\prime \prime} \mathrm{S}, 60^{\circ} 56^{\prime} 23^{\prime \prime} \mathrm{W}, 45 \mathrm{~m}$ above sea level). Both individuals were found calling at night from riparian vegetation over a small clear water stream, located about $500 \mathrm{~m}$ inside the northern trail from the research camp. Both individuals were calling from the upper side of leaves, the first about $1 \mathrm{~m}$ high, and the second about $3 \mathrm{~m}$ high. No egg clutches were found on the same or neighboring leaves.

The three specimens were deposited in the herpetology collections at Instituto Nacional de Pesquisas 
da Amazônia, in Manaus, Brazil (INPA-H 25492, 28600, 28601). Collection permits were provided to A.P. Lima and F.B.R. Gomes by RAN-ICMBio/IBAMA (permits no $13777-2$ and 22612-1, respectively).

The present records of Hyalinobatrachium cappellei are located approximately $750 \mathrm{~km}$ southward of the closest northern record, in Venezuela (Myers and Donnelly 1997), and $672 \mathrm{~km}$ northward its record in Mato Grosso state (Figure 2). These findings partially fill the previous large geographic distribution gap of this species in Central Amazonia, confirming $H$. cappellei as geographically widespread in the Amazon Basin.

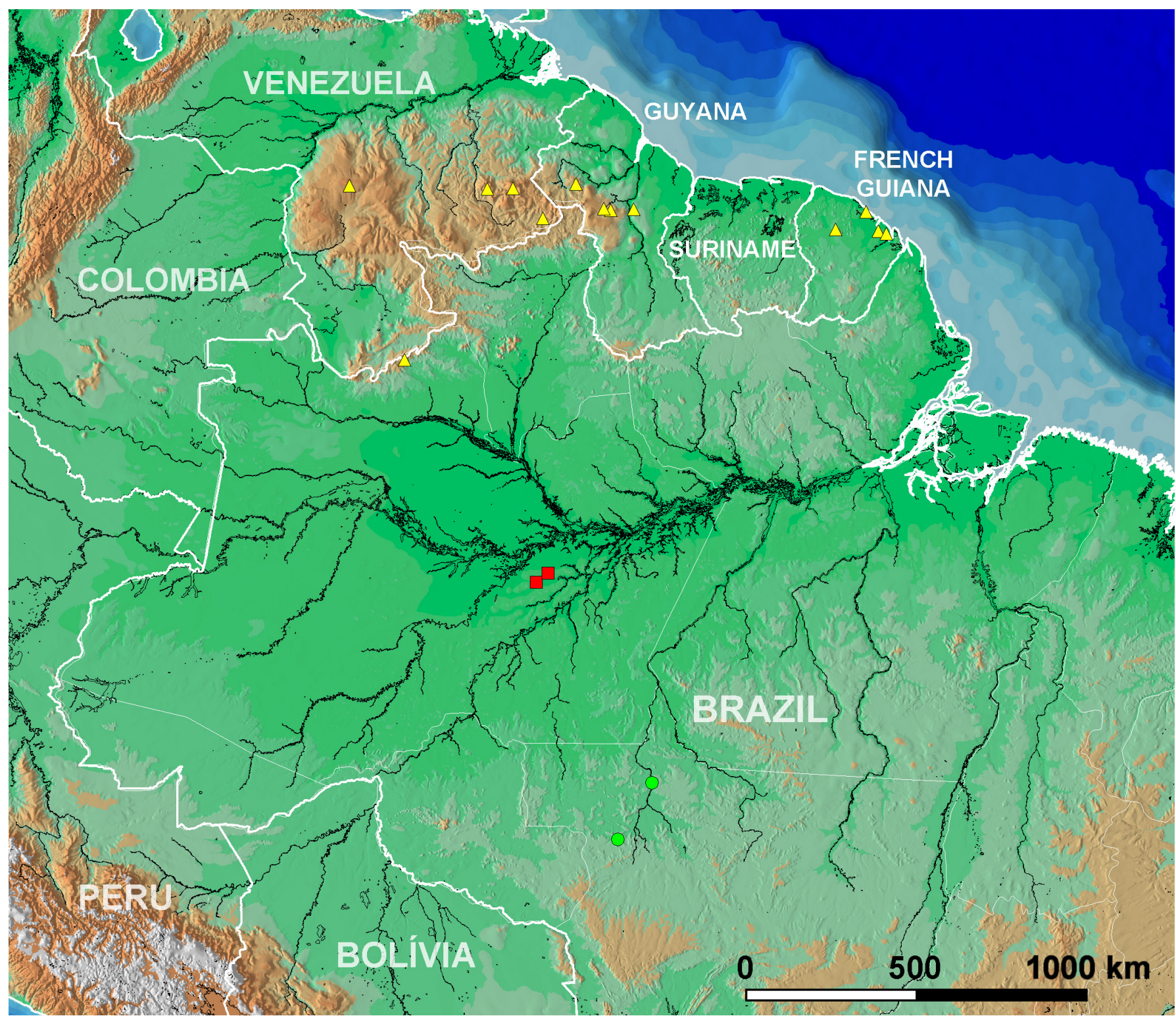

FIGURE 2. Known records of Hyalinobatrachium cappellei (van Lidth de Jeude, 1904). Red squares: the two new records, Municipality of Careiro, southwest of Manaus, Amazonas state, Brazil (this study). Yellow triangles: records in the Guiana Shield, based on geo-referenced vouchers analyzed by Castroviejo-Fisher et al. (2011). Sampling points in Suriname, including type locality at Saramacca River, are not shown due to lack of coordinates. Green dots: Two recent records in southern Amazonia (Rodrigues et al. 2010). Black lines are the hydrography, white lines the political boundaries, and colors in the background represent topography.

ACKNOWLEDGMENTS: We are grateful to Santiago Castroviejo-Fisher for the careful revision of the manuscript and help with species identification. Conselho Nacional de Desenvolvimento Científico e Tecnológico (CNPq) and Fundação de Amparo à Pesquisa do Estado do Amazonas (processes 1600-2006 and 586-10 PRONEX) provided financial support for field work. The Program for Biodiversity Research (PPBio) provided logistic support. P.I.S. received a research fellowship from CNPq (PCI/CNPq-INPA, Proc. 300975/2011-2) while conducting this study.

\section{Literature Cited}

Castroviejo-Fisher, S., C. Vilà, J. Ayarzagüena, M. Blanc and R. Ernst. 2011. Species diversity of Hyalinobatrachium glassfrogs (Amphibia: Centrolenidae) from the Guiana Shield, with the description of two new species. Zootaxa 3132: 1-55.

Goin, C. 1964. Distribution and synonymy of Centrolenella fleischmanni in northern South America. Herpetologica 20: 1-8.
Myers, C.W. and M.A. Donnelly. 1997. A tepui herpetofauna on a granitic mountain (Tamacuari) in the borderland between Venezuela and Brazil: report from the Phipps Tapirapecó Expedition. American Museum Novitates 3213: 1-71.

Rodrigues, D.J., M.M. Lima, D.H. Morais and R.A. Kawashita-Ribeiro. 2010. Amphibia, Anura, Centrolenidae, Hyalinobatrachium crurifasciatum Myers and Donnelly, 1997: First record from Brazil and geographic distribution map. Check List 6(3): 392-394.

RECEIVED: November 2011

ACCEPTED: May 2012

Published OnLine: August 2012

EDITORIAL RESPONSIBILITY: Davi L. Pantoja 